\title{
Commercial Thermal Technologies for Desalination of Water from Renewable Energies: A State of the Art Review
}

\author{
Jhon Jairo Feria-Díaz ${ }^{1,2, *(\mathbb{D})}$, María Cristina López-Méndez ${ }^{1}\left(\mathbb{D}\right.$, Juan Pablo Rodríguez-Miranda ${ }^{3}$, \\ Luis Carlos Sandoval-Herazo ${ }^{1}$ (D) and Felipe Correa-Mahecha ${ }^{4}$ (D)
}

1 División de Estudios Posgrado e Investigación, Tecnológico Nacional de México/Instituto Tecnológico Superior de Misantla, Misantla 93821, Mexico; mclopezm@misantla.tecnm.mx (M.C.L.-M.); lcsandovalh@gmail.com (L.C.S.-H.)

2 Facultad de Ingeniería, Universidad de Sucre, Sincelejo 700001, Colombia

3 Facultad del Medio Ambiente y Recursos Naturales, Universidad Distrital Francisco José de Caldas, Bogotá 11021-110231588, Colombia; jprodriguezm@udistrital.edu.co

4 Facultad de Ingeniería, Fundación Universidad de América, Bogotá 111321, Colombia; felipe.correa@profesores.uamerica.edu.co

* Correspondence: jhon.feria@gmail.com

Citation: Feria-Díaz, J.J.;

López-Méndez, M.C.;

Rodríguez-Miranda, J.P.;

Sandoval-Herazo, L.C.;

Correa-Mahecha, F. Commercial

Thermal Technologies for

Desalination of Water from

Renewable Energies: A State of the

Art Review. Processes 2021, 9, 262.

https://doi.org/10.3390/pr9020262

Received: 30 December 2020

Accepted: 27 January 2021

Published: 29 January 2021

Publisher's Note: MDPI stays neutral with regard to jurisdictional claims in published maps and institutional affiliations.

Copyright: (c) 2021 by the authors. Licensee MDPI, Basel, Switzerland. This article is an open access article distributed under the terms and conditions of the Creative Commons Attribution (CC BY) license (https:/ / creativecommons.org/licenses/by/ $4.0 /)$.

\begin{abstract}
Thermal desalination is yet a reliable technology in the treatment of brackish water and seawater; however, its demanding high energy requirements have lagged it compared to other nonthermal technologies such as reverse osmosis. This review provides an outline of the development and trends of the three most commercially used thermal or phase change technologies worldwide: Multi Effect Distillation (MED), Multi Stage Flash (MSF), and Vapor Compression Distillation (VCD). First, state of water stress suffered by regions with little fresh water availability and existing desalination technologies that could become an alternative solution are shown. The most recent studies published for each commercial thermal technology are presented, focusing on optimizing the desalination process, improving efficiencies, and reducing energy demands. Then, an overview of the use of renewable energy and its potential for integration into both commercial and non-commercial desalination systems is shown. Finally, research trends and their orientation towards hybridization of technologies and use of renewable energies as a relevant alternative to the current problems of brackish water desalination are discussed. This reflective and updated review will help researchers to have a detailed state of the art of the subject and to have a starting point for their research, since current advances and trends on thermal desalination are shown.
\end{abstract}

Keywords: desalination; multi effect distillation; multi stage flash; vapor compression distillation; renewable energies

\section{Introduction}

Water on the planet is apparently abundant; however, most of it is salt water, represented as seawater in a high percentage. Seawater is not suitable for human consumption or for most man-made processes. Furthermore, distribution of fresh water throughout the world is not uniform. In some places, fresh surface or groundwater is abundant in sparsely populated places, such as Scandinavia, Alaska, parts of southern South America, northern Russia and Canada. In contrast, there are densely populated areas with growing industrial areas, located in sites with a low fresh water availability; consequently, subjected to a high degree of water stress according to the relationship between demand for water and amount of water available [1]. As stated by the United Nations, more than two billion people in the world live in countries facing high water stress [2], an aggravated situation if UNESCO's projections for the period from 2017 to 2028 are considered, where it predicts a greater demand for water not only for agriculture, whose consumption is $70 \%$ of the demand worldwide, but also for energy production and generation [3]. Similarly, climate 
change, world population growth, contamination of fresh water sources, accelerated urbanization in cities and expansion of public service networks also contribute to global water stress [4,5]. The World Water Program (WWP) hast estimated that by 2030 only $60 \%$ of water demanded will be available for consumption. Furthermore, the Organization for Economic Cooperation and Development (OECD) predicted that by 2050, availability will be lowered up to $55 \%$ and by the end of the century, $40 \%$ of the world's population will live areas water stress regions [6].

Using seawater as a source of fresh water supply could be a solution to the increasing global water stress. Nonetheless, intensive energy requirements and prohibitive costs of desalination technologies restrain their massive use in many communities affected by water scarcity, even though having unlimited access to seawater [7,8]. Based on the International Desalination Association (IDA), in 2017, total capacity of all operating desalination plants worldwide was of 92.5 million $\mathrm{m}^{3} / \mathrm{d}$ [3]; however, the electrical or thermal energy used in the desalination process represents about $50 \%$ of the total cost of production [9]. The energy amount required for a desalination process depends on the quality of input water, level of water treatment, treatment technology used by the facility, and the treatment plant capacity $[7,10,11]$. As a substitute or replacement for electrical energy, desalination systems powered by renewable energies represent a real alternative to reduce operating costs in conventional desalination systems $[12,13]$. Table 1 shows the energy required to produce $1 \mathrm{~m}^{3}$ of fresh water from distinct types of water sources.

Table 1. Energy requirements for different water sources.

\begin{tabular}{cc}
\hline Water Source & Energy $\left(\mathbf{k W h} / \mathbf{m}^{\mathbf{3}}\right)$ \\
\hline Seawater & $2.58-8.5$ \\
Wastewater reuse & $1.0-2.5$ \\
Wastewater treatment & $0.62-0.87$ \\
Groundwater & 0.48 \\
\hline
\end{tabular}

Source: Reproduced from Refs. [7,14,15].

Generally, water desalination processes can be classified into phase change or thermal processes, and processes without phase change or by membranes $[1,4,7,16-20]$. The phase or thermal change process involves evaporation of salt water by contact with a heating surface (evaporation surface) leaving the salts in it; then, the fresh water vapor condenses in cooling pipes producing high-pressure water with quality and without salts [21].

The phase change or thermal technologies, available and of great commercial use, are Multi Effect Distillation (MED), Multi Stage Flash Distillation (MSF), Mechanical Vapor Compression (MVC), and Thermal Vapor Compression (TVC) $[1,17,22,23]$. Similarly, there are technologies that directly use solar radiation as an energy supplier, such as Solar Still (SS), Solar Chimney (SC), and Humidification/Dehumidification (HDH) [24], although they are not currently commercially available on a large scale. Desalination process without phase change consists of the use of membranes or any other element or material to directly separate the dissolved salts in the water, applying high doses of energy or pressure. Membrane techniques include Microfiltration (MF), Ultrafiltration (UF), Nanofiltration (NF), Membrane Bioreactor (MB), Membrane Distillation (MD), Electrodialysis (ED), and Reverse Osmosis (RO) [25]. These are pressure-driven processes to remove particles, bacteria, and salts from water by size exclusion through membranes with different pore sizes [26,27].

A diagram of the different technologies available for desalination of seawater or brackish water is shown in Figure 1. 


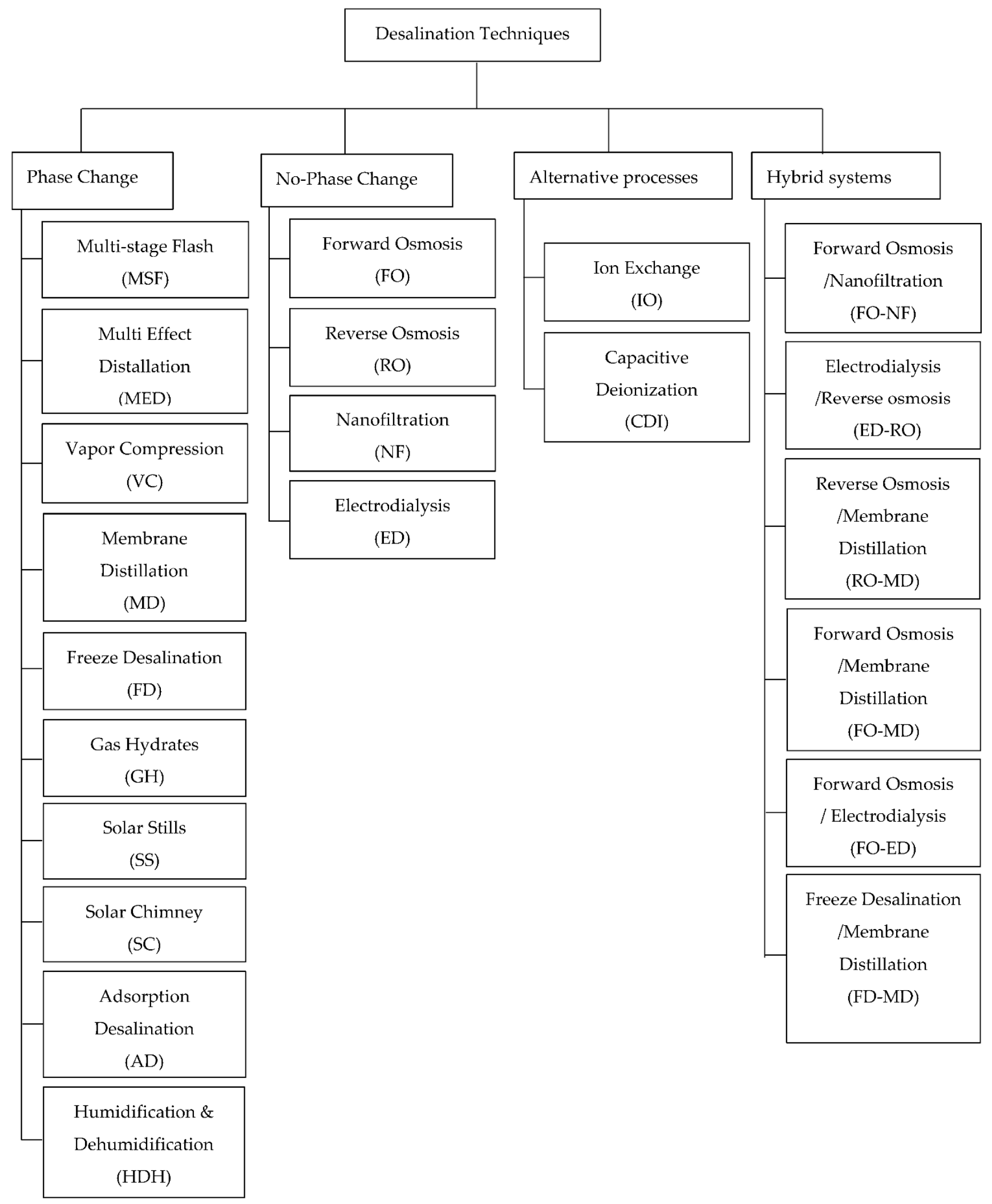

Figure 1. Available desalination technologies. Source: Adapted from Refs. [4,17,19,24].

Hybrid technologies for water desalination, such as thermal processes with reverse osmosis, have been developed since the end of the last century [28]. Similarly, the combined benefits of the high separation efficiency of MSF with the low energy consumption of RO 
have been highlighted [29]. Nowadays, hybrid desalination technologies cover a broad spectrum, including the integration of $\mathrm{RO}$ with other membrane processes, such as ED with MD, and hybridization of RO or MSF with other technologies emerging desalination [4].

This paper aims to present a profound literature review of the different commercial phase-change (thermal) desalination technologies that currently exist and present an overview of the use of renewable energy in water desalination systems and their future perspectives as a contribution to the sustainability of the water resource.

\section{Phase Change Technologies}

The main thermal desalination processes of great commercial use are: MSF, MED and MVC, with a market share of commercial desalination plants of $87.3 \%, 12.5 \%$, and $0.2 \%$, respectively. Other types of thermal desalination processes such as SS, HDH, and freezing are not found commercially and are limited to experimental prototypes or conceptual designs [30]. The characteristics of the main commercial use thermal desalination techniques and the development of the different optimization strategies for each of these technologies are shown below.

\subsection{Multi Effect Distillation (MED)}

The MED process was the first thermal process implemented in desalination of seawater for consumption. Small MED plants with capacities less than $500 \mathrm{~m}^{3} /$ day were introduced to the desalination industry in the 1960s [30,31]. The MED systems have a series of stages or phases, with a decreasing pressure gradient. A heat source is used to increase the temperature of the input water up to $110^{\circ} \mathrm{C}$ for the first phase. This heat can be initiated from a boiler running on fossil fuels, waste heat, or renewable resources. Steam is generated in a serial pattern and, in the first stage, it is transferred through a tube to subsequent stages to further boil seawater [32]. This is a medium to high capacity desalination method, where the created vapors are condensed, to give the necessary enthalpy of condensation to the seawater that feeds the system [33]. A scheme of the MED desalination process is shown in Figure 2.

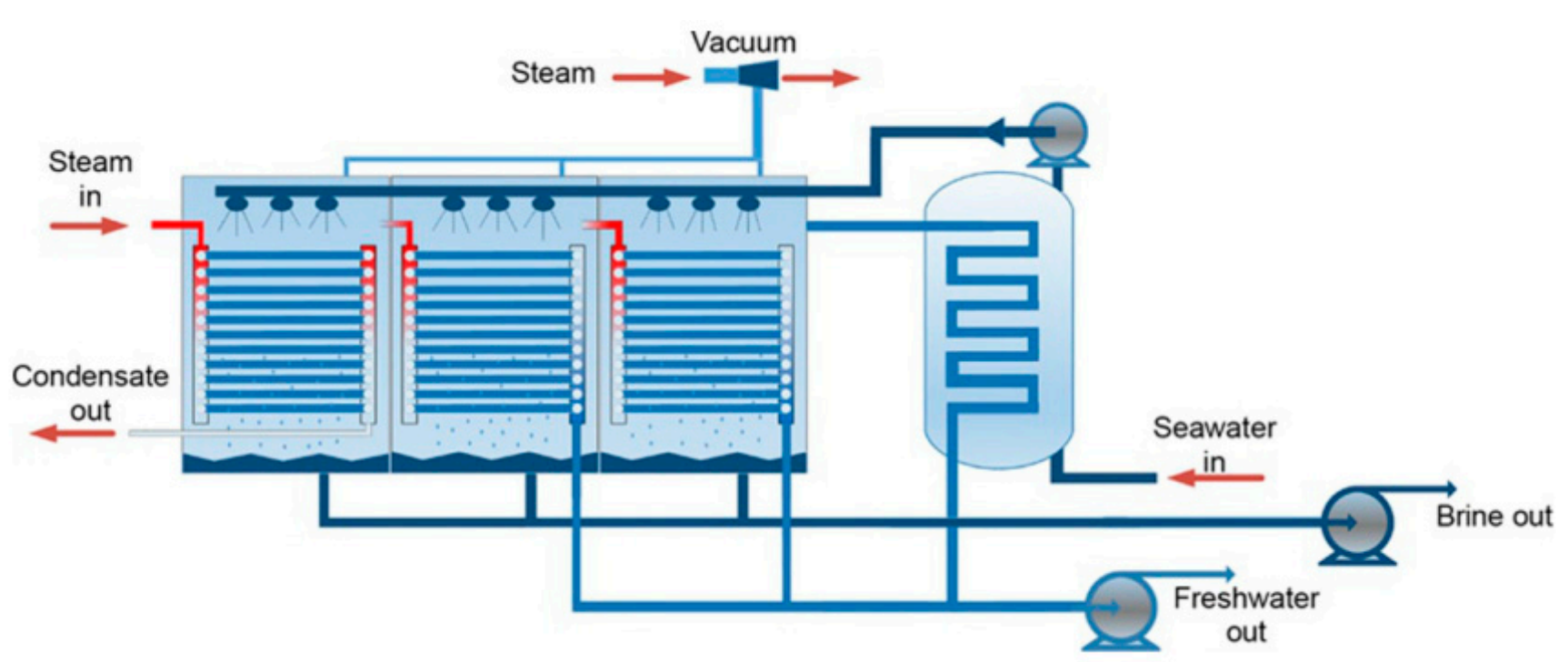

Figure 2. Schematic representation of the Multi Effect Distillation process, MED. Source: Reproduced with permission from Ref. [32].

Industrial MED systems include up to 12 evaporation effects, giving them a water production capacity from 600 to $30,000 \mathrm{~m}^{3} /$ day. The evaporation in the first phase is driven by the steam extracted from the cogeneration boilers. The steam formed in the first phase is used to drive evaporation in the second effect. This process continues with subsequent phases until the phase temperature drops to around $30-40^{\circ} \mathrm{C}$. Most industrial 
MED systems are designed to operate autonomously, where part of the steam formed in the last phase is compressed to the desired temperature and is used to drive evaporation in the first phase [30].

Among the desalination processes, the MED thermal process is a promising one due to its low electrical energy consumption, low operating cost, and high thermal efficiency $[11,34]$. Based on the energy consumption and heat transfer, MED is more efficient than MSF $[21,35,36]$. In addition, it has also been shown that MED when combined with other thermal technologies such as MSF and TVC, present higher efficiencies and performance [37]. Similarly, optimization of MED-TVC has been reported when RO is added, achieving greater heat recovery, lower energy costs, lower brine flow and lower salinity in fresh water $[38,39]$. Hybrid configurations are increasingly promising and efficient than traditional standard thermal desalination configurations.

In the past five years, MED systems research has been focused on five main topics: (1) Simulation with computational models, (2) MED process optimization, (3) waste heat recovery, (4) hybrid systems, and (5) simulations with alternative energies.

On the first topic, steady-state mathematical modeling has been used to simulate parameters that control the MED process [40-43]. These models have been useful to optimize investment and operating costs, and determine the specific value of fresh water based on each MED plant capacity. Theoretical and experimental simulations have also been implemented. Several researchers have simulated different MED configurations [44,45]; in some cases, achieving a reduction of up to $50 \%$ in energy and $30 \%$ in operating costs compared to a conventional configuration [46]. Among configurations that have aroused great interest, there is the tube-bundle [47] and Boosted MED technology [48], offering greater thermodynamic and economic performance. Normally, results of simulations and economic analyzes showed that decreasing the amount of extraction vapor in MED can significantly reduce the cost of fresh water production $[49,50]$.

On the second topic, MED process optimization has been focused on the preheating of water entering the system and evaporation by spraying. The configurations that implemented seawater preheating increased the performance ratio by up to $10 \%$ [51], even recording an average daily performance ratio of 2.5 and an average specific thermal energy consumption of $831 \mathrm{~kJ} / \mathrm{Kg}$, using thermal storage tanks and solar collectors [52]. According to the conducted simulations, with the use of the Spray Evaporation Tank, high evaporation efficiencies can be achieved if the required injection/spray parameters, the correct ratio between the water droplet size, and the fall distance are used in conjunction with the temperature of the warm air vapor $[53,54]$. Similarly, it was shown that the lowest cost of freshwater production is obtained with 17 effects, for certain operating conditions [55]. The third topic shows the viability of the use and recovery of residual heat emitted by industrial furnaces and combustion gases, and its convenience compared to conventional systems [56,57]. Use and recovery of waste heat in MED systems can increase exegetic efficiency by up to $7.34 \%$ [58]. Correspondingly, energy recovery through salinity differences in the utilized brine [59], and the use of heat adsorption pumps [60] can serve to optimize the MED system performance.

The fourth topic on hybrid systems with MED shows the development of different MED simulations integrated with other desalination technologies, mainly with TVC. Particularly, convenience of hybrid MED and TVC systems, coupled to power supply systems with solar plants, has been demonstrated. The optimization of this type of systems allowed distillate production to increase by $16.62 \%$ and the total exergy to decrease by $3.58 \%$ [61-63]. MED and TVC with self-adjusting ejectors have also been simulated to improve the Hybrid system performance [64]. Other desalination systems have been proposed to be coupled with MED, among which are the hybridization of MED with AD [65], MED with Reverse Electrodialysis [66], and MED with MD [67], showing very promising results. Nonetheless, none of these prototypes have been brought to commercial scale and are currently in the research and development stage. Finally, the fifth topic of MED simulations with alternative energies is the one that has caused the most interest among researchers. Several studies 
have shown that there are many potential ways to hybridize MED with renewable energies, such as geothermal [68] and concentrated solar energy [69-71]. Theoretical and practical simulations conducted with specialized software in pilot plants, were able to define the optimal criteria for design, optimization, and evaluation of the technical feasibility of future MED systems installations, partially powered by solar energy [72-75]. It has been shown that, in areas with high solar radiation, solar fields can produce much more thermal energy than required by MED units $\left(65^{\circ} \mathrm{C}\right.$ minimum $)$ [76], allowing annual production of fresh water to double, if a heating vapor temperature of $90{ }^{\circ} \mathrm{C}$ is used instead of $65^{\circ} \mathrm{C}$ [77]. Linear Fresnel-type solar collectors have also been used as an alternative for direct supply of solar energy in MED systems [78]. In Qatari operating conditions, $1 \mathrm{~m}^{2}$ of this type of linear collector produces $8.6 \mathrm{~m}^{3}$ of fresh water annually $[79,80]$. Hybrid MED systems powered by solar energy have shown, under certain operating conditions, to be more efficient than those powered only with electrical energy since the operating costs of desalination plants are reduced [81,82]. On the other hand, optimal design of a thermal storage tank coupled to MED reduces cost of distillate by $19 \%$ and increases the capacity factor from $46 \%$ to $75 \%$ [83,84]. However, only as MED plants powered by solar radiation increase their production capacity, it is possible to reduce production costs associated with the final value of fresh water [85]. Moreover, it has been shown that coupling solar fields to thermal desalination systems and commercial power grids, drastically reduces the environmental impact on the surroundings [86].

\subsection{Multi Stage Flash Distillation (MSF)}

The basic principle of the MSF distillation technique is flash evaporation. The MSF process distills seawater by vaporizing part of the water in various stages under vacuum, arranged in series [87]. In this process, the evaporation of seawater takes place by reducing the pressure rather than increasing the temperature. To get the maximum output and maintain MSF economies, regenerative heating is generally performed. Therefore, this process needs distinct stages for its completion and it is necessary to gradually raise the temperature of the incoming seawater at each stage [88]. In modern MSF plants, multi-stage evaporators in which there are between 19 and 28 stages, are used [89]; although other authors report the number of stages between 4 and 40, which allows the systems of MSF to produce volumes of water in the order of 10,000 to $40,000 \mathrm{~m}^{3} /$ day [90]. The operating temperature of the MSF plant is in the range of 90 to $120^{\circ} \mathrm{C}$.

The first MSF plant was built in the 1950s, however, despite the fact that multi stage flash desalination is an energy-intensive distillation process requiring both thermal and electrical energy [32], it was only in 1974 that the Federal Republic of Germany and Mexico developed in Mexican territory, a MSF plant powered by solar energy with a capacity of $10 \mathrm{~m}^{3} / \mathrm{d}$ with brine recirculation. It had parabolic trough collectors, a double tube flat plate collector, storage tanks and a desalination unit in the plant [90]. MSF's largest desalination plants are in the Persian Gulf. The Saline Water Conversion Corporation's Al-Jubail plant in Saudi Arabia is the largest plant in the world, with a capacity of around $815,120 \mathrm{~m}^{3}$ /day [89], while MSF's largest unit located in the United Arab Emirates, is the Shuweihat plant with a capacity of $75,700 \mathrm{~m}^{3} /$ day [3].

Among the advantages of the MSF system for seawater desalination, there is the reliability for large-scale production of distilled water, tolerance to the quality of the supply seawater, and the high quality of the distilled water. However, this technology has the disadvantages of high energy consumption and that the plant is heavy and expensive [91]. A schematic of MSF is shown in Figure 3. 


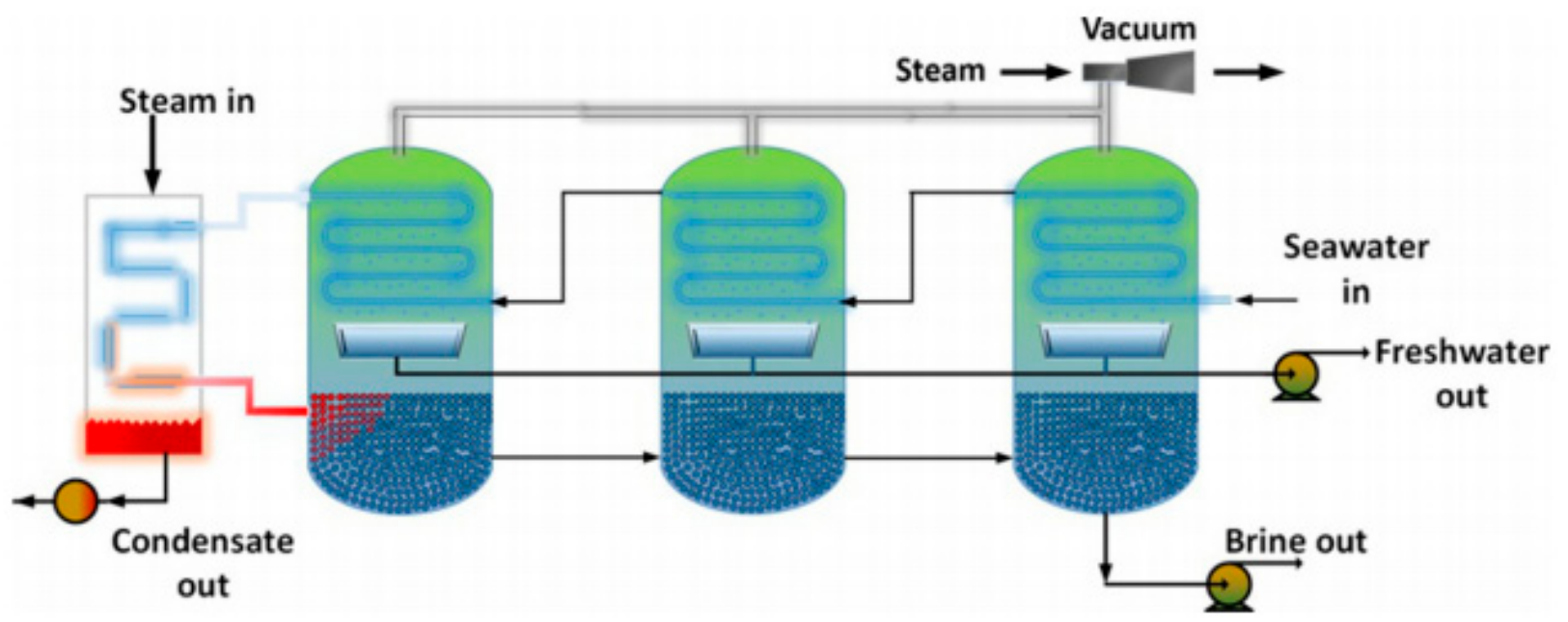

Figure 3. Schematic representation of the Multi-Stage Flash Distillation process, MSF. Source: Reproduced with permission from Ref. [32].

With the MSF process, the seawater input is pressurized and heated to the maximum permitted plant temperature. When heated liquid is discharged into a chamber held slightly below the saturation vapor pressure of water, a fraction of its water content is converted to steam. Flash vapor is removed from suspended brine droplets as it passes through a mist eliminator and condenses on the outer surface of the heat transfer pipe. The condensed liquid drips into trays as hot fresh water [92].

Nowadays, several commercial software has been widely used as a modeling and optimization tool for MSF and for other desalination technologies, serving as a basic input in the subsequent design of more complex and larger desalination systems [93]. Hybrid desalination processes based on MSF and RO have also been modeled and optimized, since the combination of these two technologies has greater comparative advantages, such as high general availability, low energy demand and better quality of treated water [94,95].

Research carried out for optimization of MSF units has been focused on exergy and energy savings, process optimization to reduce production costs, and environmental management [96]. Moreover, as in MED for MSF systems, aspects of hybridization and coupling with alternative energies have been research.

By means of exergetic and exergo-economic modeling, fresh water production in MED showed to be significantly higher than MSF (1000 vs. $1521 \mathrm{~kg} / \mathrm{s}$ ) [97]. Nonetheless, it is possible to produce $9000 \mathrm{~m}^{3}$ /day of distilled water in MSF plants with $30,000 \mathrm{~m}^{3} /$ day of brine, albeit with exergy destruction rates of $71 \%$ [98]. In addition, entropy analysis for various MSF configurations have shown that heat transfer is responsible for $65 \%$ to $85 \%$ of total exergy irreversibility for each MSF stage [99]; however, it is possible to attenuate the consumption of the water specific energy by using condensing steam turbines [100]. On the other hand, an energy analysis carried out at MSF shows that the greatest destruction of exergy occurs in the pumps and motors of the system [101]. Furthermore, it is feasible to reduce exergy destruction in the pumps by more than $39 \%$, in the distillate stream by $29 \%$, and in the purge by $30 \%$, based on optimal MSF settings [102].

For the optimization of MSF systems, simulations have been conducted with software and with experimental monitoring. Both techniques have established that MSF operation on a large scale in cold regions is cheaper than in warm regions due to energy savings in water pumping; fact that should be considered in future large-scale desalination plants [103]. Simulation models with software include simultaneous solutions of mass, moment, and energy; phase equilibria; and seawater properties as a function of temperature, pressure, and salinity [104]; even though, vapor temperature is the only factor that has a significant and positive effect on the distillate flow rate and production-profit ratio [105]. 
MSF optimization aims to solve two clearly identified MSF problems: required heat supply, especially in remote areas, and high feedwater rejection rate [106]. Recent studies reported that, by reducing the atmospheric pressure in one of the instantaneous vacuum chambers by $20 \%$, the distillation-evaporation ratio improved by $53 \%$ and the specific energy consumption was reduced by $35 \%$ [107]. Similarly, use of deflectors, special pipes, and sprayers has been proposed in MSF optimization. Simulations that used vertical deflectors and/or changed the deflector angle showed a significant increase in MSF performance [108]. Amount of produced fresh water can be increased by using improved tubes instead of conventional smooth tubes and sprayers to increase the flash evaporation rate $[109,110]$. Another optimization strategy for MSF consists of brine recirculation [111-116]. With it, MSF can increase the performance coefficient up to 4.4 [117]. On the other hand, incorporation of TVC into MSF in large-scale systems has been simulated with satisfactory results in the performance ratio of this hybrid system $[118,119]$ whereas, at the prototype scale, the development of hybrid systems MSF with FO has proven to be desirable if FO is configured as the system feedwater pretreatment $[120,121]$.

Finally, MSF systems, powered by solar energy to produce electricity and fresh water, have also been thermodynamically modeled, using energy and exergetic approaches [122,123]. The use of parabolic trough collectors (PTC), with an area of $3160 \mathrm{~m}^{2}$, can provide approximately $76 \%$ of the energy requirements demanded by an MSF system [124]. Solar energy use by means of PTC makes possible to generate enough energy to achieve high volumes of fresh water in installed MSF plants, with a value of up to USD \$2.72 per cubic meter of produced water $[125,126]$, representing an immense potential of alternative energies in optimizing and reducing the operating costs of these thermal desalination systems.

\subsection{Vapor Compression Distillation (VCD)}

$\mathrm{VCD}$ is a process used for the evaporation of contaminated saline water, in which the compressed vapors release latent heat. In the vapor compression distillation process, the function of the compressor is to compress the vapors, to increase both their temperature and pressure. Therefore, the latent heat released during the condensation process can be reused to create more vapor [127]. In vapor compression desalination systems, the feed saltwater is heated from the uncondensed vapor, which is mechanically or thermally compressed. The resulting vapor during evaporation overheats due to the increase in the brine boiling point at a pressure lower than the saturation pressure of clean water. If this vapor is compressed to a higher pressure, its temperature increases due to the input of supplementary energy. By increasing its pressure and temperature to the desired level, it can be used as a heat source for the evaporation of brackish water or seawater [33].

Although the principle of compression distillation was known before the 1970s, due to limitation of compressor technology, compression distillation in the seawater desalination field developed slowly. From 1970, with the high-efficiency centrifuge, some difficult problems of the compressors were faced, such as overweight, slow rate, large size, and especially, the compressor shaft sealing technology. Today, the compression distillation technology is quite mature and has become the chosen technology to be combined with other desalination technologies to save energy and reduce costs of the system. For instance, it is possible to obtain high values of the GOR performance index (Gain Output Ratio) in multiple effect stills (MED) when a vapor compressor is coupled to the system, thus improving the unit thermal performance [87,91].

According to the use of devices and energy in the compression process, the compression distillation process is divided into MVC and TVC, where the mechanical compressor works with electricity and the thermal compressor uses an ejector of steam jet to create vacuum [33]. Normally, the production rate of distilled water from MVC (100 to $3000 \mathrm{~m}^{3} /$ day) is lower than that of TVC (10,000 to $30,000 \mathrm{~m}^{3} /$ day) [32]. Figure 4 shows the schematics of the MVC and TVC processes, respectively. 


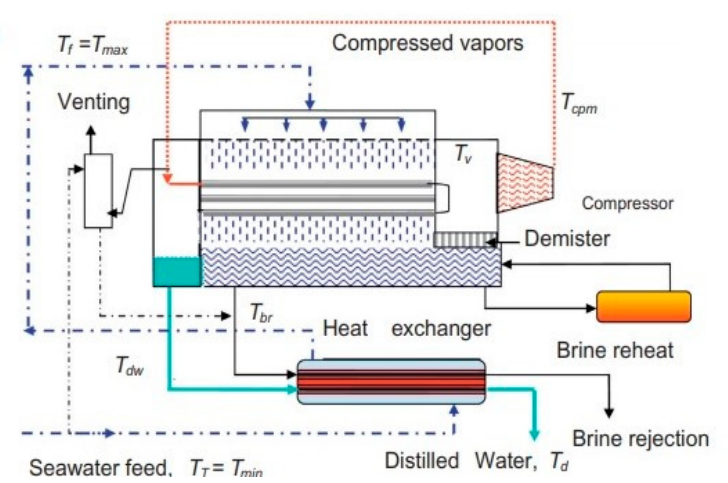

(a)

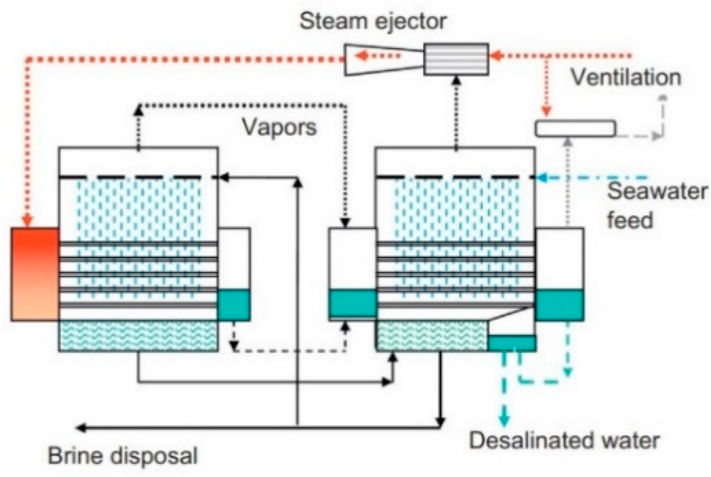

(b)

Figure 4. Schematic representation of the process: (a) MVC and (b) TVC. Source: Reproduced with permission from Ref. [33].

Among the advantages that vapor compression distillation (VC) systems have are the high efficiency of converting heat into work, the reduced volume compared to other distillation systems, they do not require large-scale heat sources and that the compressor works with electricity or with diesel engines, so they are suitable for implementation on ships, islands, and maritime bases, i.e., on a reduced scale. Nonetheless, disadvantages are the delicate boiler design and that the scale of water production is limited by the capacity of the compressor [128].

In modern desalination systems with MED, it is common to couple Vapor Compression units, configuring a hybrid treatment system with the ability to reduce specific energy consumption, thermo-economic costs and represent a feasible option in the sustainable management of brine $[129,130]$. Similarly, hybrid systems have been proposed consisting of compression vapor distillers and humidification and dehumidification units (HDH) to recover the residual heat from the system and improve its efficiency and performance [131].

Most recent publications regarding Vapor Compression Distillation technologies have been focused on thermodynamic and economic modeling aiming to optimize production costs, hybrid systems with thermal and non-thermal technologies, and on VCD systems input with alternative energies. Authors such as Randon and collaborators [132] highlight that MVC system is a very suitable technology for treating high hardness water, economically and efficiently. It must be considered, though, that input parameters used in thermo-economic analyzes have a notable influence on the final value of the cubic meter of distilled water [133]. Nevertheless, it is possible to demonstrate the economic viability of the MVC system to produce fresh water by means of mathematical simulations based on exergy and energy analysis [134]; in addition to achieve the zero emissions targets [135]. On the other hand, TVC systems are coupled to spray-assisted low desalination processes (SLTD) to make these systems economically viable [136,137].

It is worth mentioning the growing interest in the development of hybrid systems that TVC uses to optimize MED systems, due to the high quality of the fresh water produced [138] and the high system performance, if adequate control of operational parameters is carried out $[139,140]$. In this sense, use and improvements in the design of steam ejectors have shown increases in the performance of MED-TVC systems [141-143]. Self-adjusting ejectors can achieve higher drag ratios [144], and two-stage ejectors can achieve vacuums of approximately $5.3 \mathrm{kPa}$ [145]. Simulation results show that it is possible to improve MEDTVC designs when the compression ratio of the thermal ejector is from 2.1 to 2.6 [146,147]. Exergy and economical simulations have also been performed for hybrid MED-MVC configurations which managed to reduce total fixed production costs by $30 \%$ [148].

Hybrid VCD systems with non-thermal technologies are still in the research and development stages. For TVC-RO systems, the simulations indicate that better performances are 
obtained when they are configured in series and not in parallel and independent form [149]. Even if the configuration is MED-TVC-Reverse Osmosis, energy loss can be significantly reduced [150]. On the other hand, MVC systems have been proposed as a complement to MD and AD systems. Swaminathan and collaborators [151] coupled MVC with MD and demonstrated that this hybrid system can reduce the final cost of fresh water produced by $6 \%$ compared to an independent MVC system. Similarly, Askalany and collaborators [152] proposed a novel MVC-AD system that managed to increase the amount of desalinated water in a range of $10-45 \%$ as a function of the conduction temperature of the silica gel used.

VCD systems have also been exergetically and thermodynamically modeled, coupled to solar and wind power systems. The results of the simulations for MED-TVC powered by solar energy show important improvements in the energy performance of the hybrid system compared to when it is powered by conventional electrical energy [153-155]; even when using photovoltaic systems between $35-40 \%$ as a renewable photovoltaic contribution in hybrid TVC systems, it is the best combination possible [156].

To summarize, Figure 5 shows the number of publications made on thermal desalination systems in the last five years.

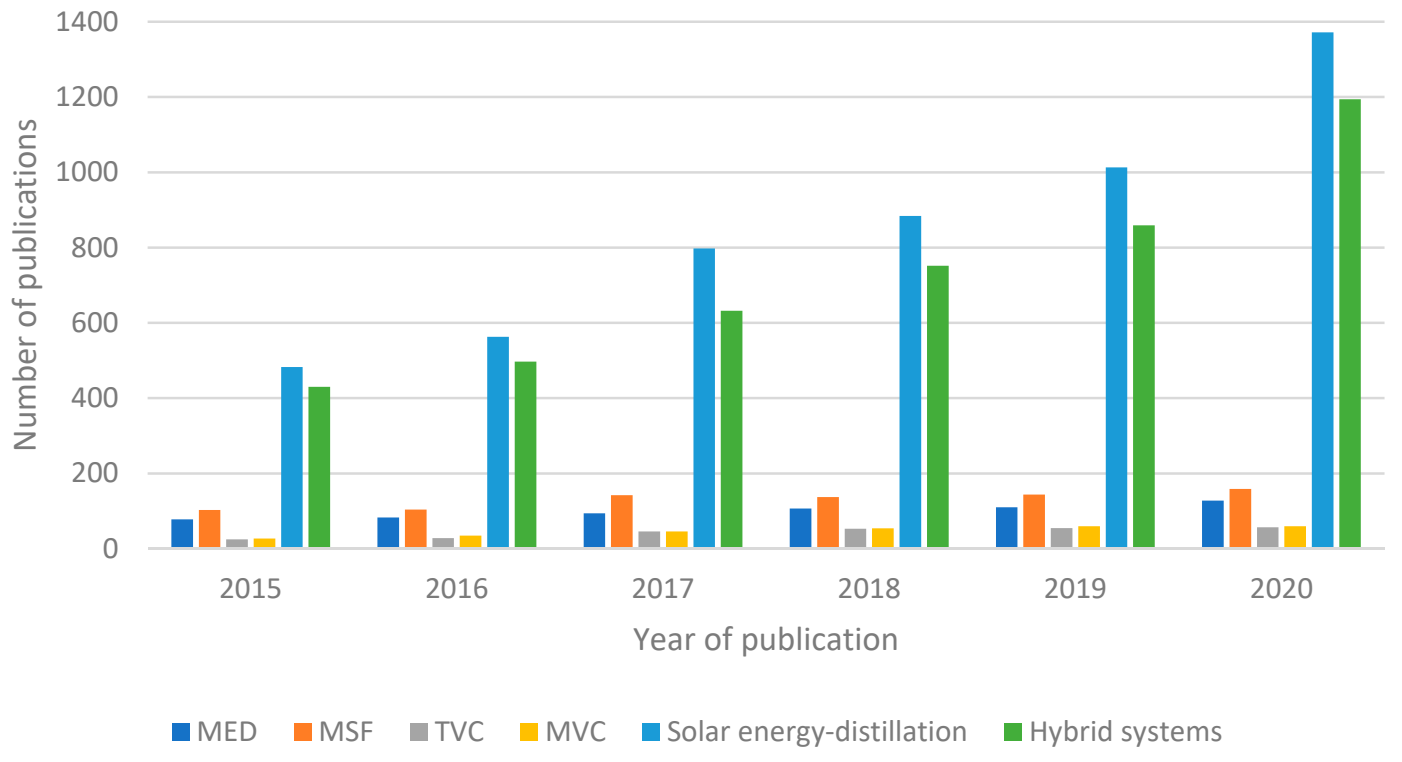

Figure 5. Number of publications on thermal desalination technologies (2015-2020).

The scientific research database, ScienceDirect, was used for this technical literature review. A clear and growing interest could be observed in research on the integration of alternative energy and desalination systems, and on the hybridization of these technologies. This tendency is mainly due to the high energy consumption required by thermal desalination systems and their technical limitations, which forces researchers to innovate in the combination of desalination techniques and the use of renewable energies.

\section{Use of Renewable Energies in Water Desalination}

To produce fresh water, conventional desalination systems demand high energy requirements, which are usually obtained from fossil fuels $[7,18]$. Table 2 shows the specific energy requirements to produce one cubic meter of fresh water from currently available technologies for commercial seawater desalination. 
Table 2. Typical total electrical energy consumptions in different desalination technologies.

\begin{tabular}{cc}
\hline Desalination Technology & Specific Energy Requirements \\
\hline Multi-Effect Distillation & $14-21 \mathrm{kWh} / \mathrm{m}^{3}$ \\
Multi-Stage Flash & $20-27 \mathrm{kWh} / \mathrm{m}^{3}$ \\
Mechanical Vapor Compression & $7-12 \mathrm{kWh} / \mathrm{m}^{3}$ \\
Thermal Vapor Compression & $16.26 \mathrm{kWh} / \mathrm{m}^{3}$ \\
Seawater Reverse Osmosis & $4-6 \mathrm{kWh} / \mathrm{m}^{3}$ \\
\hline
\end{tabular}
Source: Reproduced from Refs. [18,157].

Nevertheless, when comparing the consumption of thermal desalination plants in operation, it is possible to find specific energy requirements and losses. Table 3 shows the comparative results of energy consumption and losses in MED, MSF and MVC systems.

Table 3. Requirements and energy losses in thermal desalination systems.

\begin{tabular}{cccc}
\hline $\begin{array}{c}\text { Desalination } \\
\text { Technology }\end{array}$ & Plant Capacity & $\begin{array}{c}\text { Electric Power } \\
\text { Consumption }\end{array}$ & $\begin{array}{c}\text { Loss of Electric } \\
\text { Power }\end{array}$ \\
\hline $\begin{array}{c}\text { Multi-Effect } \\
\text { Distillation (MED) }\end{array}$ & $20,000\left(\mathrm{~m}^{3} / \mathrm{d}\right)$ & $2.5 \mathrm{kWh} / \mathrm{m}^{3}$ & $10 \mathrm{kWh} / \mathrm{m}^{3}$ \\
\hline $\begin{array}{c}\text { Multi-Stage } \\
\text { Flash (MSF) }\end{array}$ & $68,333\left(\mathrm{~m}^{3} / \mathrm{d}\right)$ & $5 \mathrm{kWh} / \mathrm{m}^{3}$ & $10 \mathrm{kWh} / \mathrm{m}^{3}$ \\
\hline $\begin{array}{c}\text { Mechanical Vapor } \\
\text { Compression (MVC) }\end{array}$ & $500\left(\mathrm{~m}^{3} / \mathrm{d}\right)$ & $8 \mathrm{kWh} / \mathrm{m}^{3}$ & - \\
\hline Source: Adapted from Ref. [158]. & &
\end{tabular}

Although the capacity of the plants analyzed is different, MED and MSF showed equal losses of electrical energy, that is, $10 \mathrm{kWh}$ for each $\mathrm{m}^{3}$ of fresh water produced; however, the electrical energy consumption in MSF was double, because in MED the heat transfer is more effective [34]. On the other hand, several options have been developed to improve the energy footprint of desalination technologies, among which is energy recycling and recovery, hybrid processes, process modifications, use of waste heat and integration with renewable energies [21]. Broadly, the efficiency of the low-temperature heat is quantified by the gain output ratio (GOR), which measures the thermal energy consumed in the desalination process, and is defined as the ratio between the mass of distillate and the mass of steam input $\left(\mathrm{kg}_{\text {distillate }} / \mathrm{kg}_{\text {steam }}\right)$. For MED, commercial manufacturers provide a GOR between 10 to 16; for MSF between 8 and 12 and for MVC, a GOR of around $12 \mathrm{~kg}_{\text {distillate }} / \mathrm{kg}_{\text {steam }}$ [11]. This explains why the high technological growth trend of MED over MSF [10], in particular, when coupled with other desalination systems to form more efficient hybrid systems, with less environmental impact and higher quality of the water produced.

Generally, thermal-based desalination techniques significantly consume more energy compared to membrane techniques [11,157]. Only 131 desalination plants in the world, representing approximately $1 \%$ of the world's water desalination capacity work with energy from renewable sources [10]. However, use of renewable energy for seawater desalination has increased from $2 \%$ in 1998 to $19.3 \%$ in 2015 [18].

The main conventional renewable energy sources for water desalination are: solar, geothermal, wind, and tidal energy. Solar and wind energy contribute predominantly to the general renewable energy capacity, and to a lesser extent, geothermal and tidal energy [159]. Photovoltaic solar energy represents $43 \%$ of the total share of renewable energies in water desalination, while solar thermal energy represents $27 \%$, wind $20 \%$ and the remaining $10 \%$ corresponds to hybrid renewable energies $[10,160]$. However, the share of renewable energies is forecast to increase progressively in the near future, albeit in combination with traditional sources, in order to minimize pressure on non-renewable fossil fuels [161]. In 
any case, renewable energies can only serve as a complement to other types of energies, due to their limitations and their unpredictable nature [162].

Selecting a suitable solar system requires many considerations, such as locally available solar radiation, plant location, energy storage method, operating temperature range, plant configuration, type of solar collector, fluid power (working fluids), among others. Most solar desalination systems have not been developed as a single system, but are integrations of independently developed components, although some systems require minor changes for better integration [163]. On the other hand, wind turbines represent a mature technology that has been present in many countries for a long time and represents a viable option as a source of energy for desalination systems; however, problems such as public acceptance, correct location of turbines, visual impact, audible noise, interference in communications, and various impacts on the natural habitat and wildlife, have hampered their full development [159]. Use of hybrid renewable solar-wind energy systems has recently been reported with excellent results in isolated islands, and thanks to these integrated generation systems, it is possible to have continuous energy, even if there is no permanent solar radiation $[164,165]$.

Concentrated Solar Power (CSP) plants have gained great interest due to the possible simultaneous cogeneration of water and electricity. The coupling of CSP to MED and RO desalination systems has been the one with the best technical and economic performance; therefore, it is the one with the greatest technological development, although commercially integrated on a small scale [157]. This is mainly because promoting thermal desalination with CSP is not economically feasible on a large scale, since the costs of the production of $1 \mathrm{~m}^{3}$ of fresh water range between US $\$ 0.94$ and US $\$ 4.31$, mostly affected due to the capital expenditure in the solar field and the operating expense of the desalination plant [166]. Consequently, desalination is a costly process if compared with the USD $\$ 0.53$ price of $1 \mathrm{~m}^{3}$ of fresh water when it is produced through a conventional process [74,92]. Although thermal desalination technologies require higher energy demands and have high maintenance costs compared to RO systems [167], both processes are key to fresh water supply. Thus, reducing their energy demands through research avance is equally important for both [7]. As a response, mathematical models and algorithms have emerged to allow simulating the costs of freshwater production with desalination systems, both thermal and membrane, coupled to diverse sources of renewable and non-renewable energy, allowing them to be compared with each other, to optimize decision-making in the selection [168]. Currently, in any case, the only desalination systems coupled with solar energy, with market opportunities and capable of producing up to $20,000 \mathrm{~m}^{3} / \mathrm{d}$ of fresh water, are based on reverse osmosis driven by parabolic or linear trough concentrators, or with concentrators of plate coupled to micro gas turbines [169].

At the experimental level, MD is among the most promising desalination technologies from the potential use of sustainable energy sources. Fresh water production rates of $3 \mathrm{~kg} / \mathrm{m}^{2} / \mathrm{h}$ have been reported with an electrical and total efficiency of the experimental system of $18 \%$ and $71 \%$ respectively, based on the use of a concentrated photovoltaic/thermal system [170]. The University of Almerias in Spain proposes the integration of a solar thermal field based on static collectors coupled to a Vacuum Multi-Effect Membrane Distillation unit (V-MEMD), the experimental results show a rate of maximum fresh water production of $5.5 \pm 1 \mathrm{~L} / \mathrm{m}^{2} / \mathrm{h}$ [43]. However, the best application of solar-assisted MD for water desalination is for domestic use in single-family homes [171], where the main drawback is the cooling requirements, like any other heating distillation technology. Therefore, membrane distillation systems, when fully developed, will have market opportunities in seawater desalination systems, but with very small production capacities [169].

Another technique that has been presenting advances and improvements for the desalination of saline waters is HDH coupled with different types of renewable energies and cooling and desalination technologies [172-174]. Recent studies reported an increase in the water production rate from 10.8 to $32.1 \mathrm{~kg} / \mathrm{m}^{2} /$ day thanks to the use of hygroscopic solutions such as kaolin [175]. The design and operation of HDH processes coupled to 
solar photovoltaic thermal modules (PVT) for the simultaneous generation of clean water and electricity has been researched; however, the final cost of $1 \mathrm{~m}^{3}$ of water is expensive with this technology, but its high electricity production makes it the cheapest solution for places in critical environmental conditions [176]. In general, it has been shown that the integration of PVT systems with water desalination systems, ensures the polygeneration of products, improves the general efficiency of desalination, and improves the environmental sustainability of these systems [177].

On an experimental scale, another desalination technology that has aroused great interest among researchers is ED coupled to photovoltaic (PV) systems [178] and to hybrid photovoltaic-wind systems [179]. In terms of renewable energy-driven desalination, ED systems are highly valued for their adaptability to varying power conditions, as they can operate at a wide range of direct current voltages [180]. ED systems are more favorable for brackish water desalination with relatively low Total Dissolved Solids (TDS), as it is normally considered to be economically uncompetitive for seawater desalination due to expensive ion exchange membranes, expensive electrodes and relatively short lifespan when working in a high-density electric field [180,181].

In short, the use of renewable energy sources for desalination is essential and decisive if we want to provide an adequate supply of clean water that meets our future needs, reduces harmful impacts on the environment, and is sustainable over time [10]. Consequently, the future of desalination with optimized energy requirements is predicted to include ultrahigh permeability membranes, scale resistant membranes, hybrid systems, and renewable energy-driven desalination [7].

Finally, within the strategies to reduce energy waste in thermal desalination plants and take advantage of the maximum useful work possible of the energy during the process (i.e., the exergy), it is possible to propose the integration of these systems with other generation systems of energy, in such a way that a "dual purpose" or "cogeneration of electricity and water" configuration is achieved. Similarly, the integration of thermal desalination processes with renewable energy sources could reduce the massive use of electrical energy from fossil fuels, thus making it more environmentally and economically sustainable [182]. Another strategy aimed at rationalizing energy consumption and taking advantage of exergy in thermal desalination systems consists of the use of system feed water preheaters, in particular MED-TVC. In this way, the energy required to preheat the feed water decreases and will evaporate upon entering the first effect of MED [183].

\section{Future Perspectives}

Despite the evident advances that commercial thermal desalination systems have had in recent decades, which has allowed a considerable increase in the flows of desalinated water produced globally, it is necessary to mitigate the intensive energy requirements to lower the high production costs and make its massive use more accessible in regions in need of this technology and with low per capita income. Present and future research is aimed at significantly improving energy savings and optimizing processes and equipment, to reduce the current limitations of thermal desalination processes. Consequently, the hybridization of technologies and the use of renewable energies is the way to go, because the availability and coupling of emerging energies with hybrid systems is currently more relevant. Considering the limitations of solar radiation as the only energy provider, it is also recommended to hybridize renewable energies to take advantage of their full potential, such as a hybrid solar and wind energy system coupled to water desalination systems.

Nowadays, the race for the next generation of seawater desalination systems has already started with RO and low-temperature MED systems. Its low cost of energy consumption gives it more advantage compared to other systems such as MSF [44]. However, research on emerging desalination technologies have clear merits and environmental benefits over RO, for which the trend is the development of hybrid MED systems with this type of emerging technologies, where the most opted is FO [22]. Additionally, considering MED's low energy consumption, it can be operated with solar energy coupled to a 
MED + TVC system. However, it is necessary to deepen research on the configuration of this process, since it is still in the development stage, but with very good prospects on a commercial scale.

On the other hand, use of Waste Heat (WH) as an optimization strategy in conventional desalination technologies has demonstrated its technical viability, since it improves the productions and efficiencies in thermal desalination processes. The use of waste heat in desalination generates significant economic and environmental benefits by eliminating or reducing fuel and energy input. In turn, this will result in the reduction of production costs of desalination and greenhouse gas (GHG) emissions associated with fuel consumption [184]; however, most waste heat driven systems are in a pilot and laboratory scale, with a clear need for further development for large-scale plants. Future planning of a new desalination facility should consider the use of available waste heat sources related to power plants or industrial parks [185].

Regarding the mathematical modeling of processes, energy and exergy analyzes should be used as key factors when applying solar energy systems to improve the energy and exergetic efficiency of the modeled systems [186]. Among the developments and research required to overcome the technological limitations that hinder the massive access of desalination technologies from renewable energies, the following can be mentioned [187]:

- Development of components, intelligent controls, and new materials that allow optimizing the coupling of desalination systems with renewable energy systems.

- Development of new types of desalination membranes that can easily and optimally hybridize with thermal desalination systems such as MED.

- Proper disposal of brine due to the high environmental impacts that its mismanagement represents.

- Deepening the coupling and extensive use of photovoltaic technology as an alternative energy supply in desalination systems.

- Optimization of solid-liquid phase separation processes in the thermal desalination of water.

- Improving the automatic management of energy loading and unloading, as they are necessary for the proper management of the maximum load of solar thermal and photovoltaic energy.

- Development of systems and equipment to improve the conversion efficiency of photovoltaic energy, because the currently available on the market is low.

- Innovation in materials for photovoltaic cells in such a way that they act independently of temperature and local climatic variables.

- It is necessary to develop prototypes and equipment where the desalination process is compact, portable, mobile, and simple in design and manufacturing to produce small-scale water from saline, brackish, and fluoridated water.

- In the thermal desalination system, overlay formation in the pipes and tubes of the heat exchanger is the main issue due to the high-water salinity. It is very difficult to remove overlays and it also reduces the heat exchanger efficiency, therefore, coming up with technical solutions to these difficulties is a need that must be addressed promptly.

- All the limitations and challenges presented can be overcome with innovative ideas and research, which beat knowledge barriers and give development opportunities to experimental research, modeling, and computational simulation. Therefore, collaboration in the field of R\&D between academia and industry is essential to transform these future technological developments into commercial products, capable of responding to the needs and problems of society.

\section{Conclusions}

Conditions of water stress that currently exist in many populated areas of the planet, and are expected to increase shortly, have led to the optimization of commercial thermal desalination systems and development of new alternative systems that, although still in the experimental stage and on a pilot scale, represent the best alternative to face this problem. 
Optimization of thermal desalination systems has been oriented towards hybridization with commercial (VCD and RO) and non-commercial (HDH, ED, MD, AD) technologies, and the reduction or replacement of electrical and combustion energy by renewable energies, especially by solar and wind, proposing alternation or simultaneity between them. All this, due to the need to reduce the equipment costs used in desalination technologies and the automation required for this type of process.

Recent research in the development of commercial thermal technologies revolves around reducing production costs, reducing impact on the environment and reducing greenhouse gas emissions; therefore, the focus is on increasing desalination efficiencies, recovering heat residual and exergy, mathematically modeling hybridization alternatives, and finally, the best is on integration with renewable energies. In this way and in the future, research will be directed towards the development of desalination technologies that allow to find inexpensive equipment, with low energy consumption and with high performance and efficiency.

Author Contributions: Writing—original draft preparation, J.J.F.-D.; writing—review and editing, F.C.-M.; Conceptualization, M.C.L.-M., L.C.S.-H. and J.P.R.-M. All authors have read and agreed to the published version of the manuscript.

Funding: This research received no external funding.

Data Availability Statement: Not applicable.

Conflicts of Interest: The authors declare no conflict of interest.

\section{References}

1. Esmaeilion, F. Hybrid renewable energy systems for desalination. Appl. Water Sci. 2020, 10, 1-47. [CrossRef]

2. WWAP (UNESCO World Water Assessment Programme). The United Nations World Water Development Report 2019: Leaving No One Behind; UNESCO Digital Library: Paris, France, 2019; p. 201.

3. Global Water Intelligence. The International Desalination Association IDA Desalination Yearbook 2017-2018; Media Analytics Ltd.: London, UK, 2017; pp. 260-275.

4. Ahmed, F.E.; Hashaikeh, R.; Hilal, N. Hybrid technologies: The future of energy efficient desalination-A review. Desalination 2020, 495, 114659. [CrossRef]

5. Nazarova, Y.A.; Sopilko, N.Y.; Kovaleva, E.A.; Kulakov, A.V.; Orlova, A.F.; Gavlovskaya, G.V. How to solve water shortage problem by means of renewable power generation? IJEEP 2009, 9, 244-249. [CrossRef]

6. Caldera, U.; Bogdanov, D.; Breyer, C. Local cost of seawater RO desalination based on solar PV and wind energy: A global estimate. Desalination 2016, 385, 207-216. [CrossRef]

7. Nassrullah, H.; Anis, S.F.; Hashaikeh, R.; Hilal, N. Energy for desalination: A state of the art review. Desalination 2020, $491,114569$. [CrossRef]

8. Gude, V.G. Desalination and sustainability_An appraisal and current perspective. Water Res. 2016, 8, 87-106. [CrossRef]

9. UNEP (United Nations Environment Programme). Water Quality: Policy Brief. Unwater; UNEP: Rome, Italy, 2018.

10. Shahzad, M.W.; Burhan, M.; Ang, L.; Ng, K.C. Energy-water-environment nexus underpinning future desalination sustainability. Desalination 2017, 413, 52-64. [CrossRef]

11. Al-Karaghouli, A.; Kazmerski, L.L. Energy consumption and water production cost of conventional and renewable-energypowered desalination processes. Renew. Sustain. Energ. Rev. 2013, 24, 343-356. [CrossRef]

12. Aboelmaaref, M.M.; Zayed, M.E.; Zhao, J.; Li, W.; Askalany, A.A.; Salem Ahmed, M.; Ali, E.S. Hybrid solar desalination systems driven by parabolic trough and parabolic dish CSP technologies: Technology categorization, thermodynamic performance and economical assessment. Energy Convers. Manag. 2020, 22, 113103. [CrossRef]

13. Kim, B.; Seo, J.Y.; Chung, C.H. A hybrid system of capacitive deionization and redox flow battery for continuous desalination and energy storage. J. Power Sources 2020, 448, 227384. [CrossRef]

14. Walsh, B.P.; Murray, S.N.; O'Sullivan, D.T.J. The water energy nexus, an ISO50001 water case study and the need for a water value system. Water Resour. Ind. 2015, 10, 15-28. [CrossRef]

15. WBCSD (World Business Council on Sustainable Development). Water, Energy, and Climate Change, A Contribution from the Business Community; Atar Roto Presse SA: Conches-Geneva, Switzerland, 2009.

16. Ahmed, F.E.; Hashaikeh, R.; Diabat, A.; Hilal, N. Mathematical and optimization modelling in desalination: State-of-the-art and future direction. Desalination 2019, 469, 114092. [CrossRef]

17. Alaei Shahmirzadi, M.A.; Hosseini, S.S.; Luo, J.; Ortiz, I. Significance, evolution and recent advances in adsorption technology, materials and processes for desalination, water softening and salt removal. J. Environ. Manag. 2018, 215, 324-344. [CrossRef] [PubMed] 
18. Abdelkareem, M.A.; El Haj Assad, M.; Sayed, E.T.; Soudan, B. Recent progress in the use of renewable energy sources to power water desalination plants. Desalination 2018, 43, 97-113. [CrossRef]

19. Alkaisi, A.; Mossad, R.; Sharifian-Barforoush, A. A Review of the Water Desalination Systems Integrated with Renewable Energy. Energy Procedia 2017, 110, 268-274. [CrossRef]

20. Xu, P.; Cath, T.Y.; Robertson, A.P.; Reinhard, M.; Leckie, J.O.; Drewes, J.E. Critical review of desalination concentrate management, treatment and beneficial use. Environ. Eng. Sci. 2013, 30, 502-514. [CrossRef]

21. Gude, V.G.; Fthenakis, V. Energy efficiency and renewable energy utilization in desalination systems. Prog. Energy 2020, 2, 022003. [CrossRef]

22. Elsaid, K.; Sayed, E.T.; Abdelkareem, M.A.; Mahmoud, M.S.; Ramadan, M.; Olabi, A.G. Environmental impact of emerging desalination technologies: A preliminary evaluation. J. Environ. Chem. Eng. 2020, 8, 104099. [CrossRef]

23. Raj, M.A.; Murugavel, K.K.; Rajaseenivasan, T.; Srithar, K. A review on flash evaporation desalination. Desalin. Water Treat. 2016, 57, 13462-13471. [CrossRef]

24. Chem, C.; Jiang, Y.; Ye, Z.; Yang, Y.; Hou, L. Sustainably integrating desalination with solar power to overcome future freshwater scarcity in China. Glob. Energy Interconnect. 2019, 2, 98-113. [CrossRef]

25. Suwaileh, W.; Johnson, D.; Hilal, N. Membrane desalination and water re-use for agriculture: State of the art and future outlook. Desalination 2020, 491, 114559. [CrossRef]

26. Honarparvar, S.; Zhang, X.; Chen, T.; Na, C.; Reible, D. Modeling technologies for desalination of brackish water-Toward a sustainable water supply. Curr. Opin. Chem. Eng. 2019, 26, 104-111. [CrossRef]

27. Younos, T.; Tulou, K.E. Overview of Desalination Techniques. J. Contemp. Water Res. Educ. 2009, 132, 3-10. [CrossRef]

28. Agashichev, S.P.; El-Dahshan, M.E. Reverse osmosis incorporated into existing cogenerating systems as a sustainable technological alternative for United Arab Emirates. Desalination 2003, 157, 33-49. [CrossRef]

29. Helal, A.M.; El-Nashar, A.M.; Al-Katheeri, E.S.; Al-Malek, S.A. Optimal design of hybrid RO/MSF desalination plants part II: Results and discussion. Desalination 2004, 160, 13-27. [CrossRef]

30. Ettouney, H. Conventional Thermal Processes. In Seawater Desalination; Micale, G., Rizzuti, L., Cipollina, A., Eds.; Springer: Berlin/Heidelberg, Germany, 2009; ISBN 978-3-642-01149-8.

31. Kress, N. Desalination Technologies. Marine Impacts of Seawater Desalination, 1st ed.; Elsevier: Amsterdam, The Netherlands, 2019; pp. 11-34. ISBN 978-0-12-811953-2.

32. Rabiee, H.; Khalilpour, K.R.; Betts, J.M.; Tapper, N. Energy-Water Nexus: Renewable-Integrated Hybridized Desalination Systems. In Polygeneration with Polystorage for Chemical and Energy Hub; Khalilpour, K.R., Ed.; Elsevier: London, UK, 2019; Volume 1, pp. 409-458, ISBN 978-0-12-813306-4.

33. Belessiotis, V.; Kalogirou, S.; Delyannis, E. Thermal Solar Desalination: Methods and Systems, 1st ed.; Elsevier: London, UK, 2016; ISBN 978-0-12-809656-7.

34. Wang, X.; Christ, A.; Regenauer-Lieb, K.; Hooman, K.; Chua, H.T. Low grade heat driven multi-effect distillation technology. Int. J. Heat Mass Transf. 2011, 54, 5497-5503. [CrossRef]

35. Hanshik, C.; Jeong, H.; Jeong, K.W.; Choi, S.H. Improved productivity of the MSF (multi-stage flashing) desalination plant by increasing the TBT (top brine temperature). Energy 2016, 107, 683-692. [CrossRef]

36. Sen, P.K.; Sen, P.V.; Mudgal, A.; Singh, S.N.; Vyas, S.K.; Davies, P. A small scale Multi-Effect Distillation (MED) unit for rural micro enterprises: Part I-Design and fabrication. Desalination 2011, 279, 15-26. [CrossRef]

37. Zak, G.M.; Mitsos, A. Hybrid thermal-thermal desalination structures. Desalination Water Treat. 2014, 52, 2905-2919. [CrossRef]

38. Al-hotmani, O.M.A.; Al-Obaidi, M.A.; Patel, R.; Mujtaba, I.M. Performance analysis of a hybrid system of multi effect distillation and permeate reprocessing reverse osmosis processes for seawater desalination. Desalination 2019, 470, 1-13. [CrossRef]

39. Filippini, G.; Al-Obaidi, M.A.; Manenti, F.; Mujtaba, I.M. Performance analysis of hybrid system of multi effect distillation and reverse osmosis for seawater desalination via modelling and simulation. Desalination 2018, 448, 21-35. [CrossRef]

40. Cunha, D.P.S.; Gomes, V.V.; Pontes, K.V. Modeling of multi-effect desalination process operated with thermosolar energy applied to the northeastern Brazil. Comput. Aided Chem. Eng. 2019, 46, 1537-1542. [CrossRef]

41. Kosmadakis, G.; Papapetrou, M.; Ortega, B.; Cipollina, A.; Alarcón, D.C. Correlations for estimating the specific capital cost of multi-effect distillation plants considering the main design trends and operating conditions. Desalination 2018, 447, 74-83. [CrossRef]

42. Palenzuela, P.; Alarcón, D.C.; Zaragoza, G. Experimental parametric analysis of a solar pilot-scale multi-effect distillation plant. Desalination Water Treat. 2016, 57, 23097-23109. [CrossRef]

43. Palenzuela, P.; Hassan, A.S.; Zaragoza, G.; Alarcón, D.C. Steady state model for multi-effect distillation case study: Plataforma Solar de Almería MED pilot plant. Desalination 2014, 337, 31-42. [CrossRef]

44. Alhaj, M.; Hassan, A.; Darwish, M.; Al-Ghamdi, S.G. A techno-economic review of solar-driven multi-effect distillation. Desalination Water Treat. 2017, 90, 86-98. [CrossRef]

45. Naserbegi, A.; Rezaei, A.; Alahyarizadeh, G.; Aghaie, M. Energy management of nuclear desalination plant by efficient coupling a pressurized water reactor and a multi-effect distillation system-thermodynamic evaluation. Desalination Water Treat. 2019, 151, 34-46. [CrossRef]

46. Cui, C.; Xi, Z.; Liu, S.; Sun, J. An enumeration-based synthesis framework for multi-effect distillation processes. Chem. Eng. Res. Des. 2019, 144, 216-227. [CrossRef] 
47. Azimibavil, S.; Jafarian, A. Dynamic simulation of a Multi-Effect Distillation (MED) process. Desalination 2016, 392, 91-101. [CrossRef]

48. Christ, A.; Regenauer, K.; Chua, H.T. Boosted Multi-Effect Distillation for sensible low-grade heat sources: A comparison with feed pre-heating Multi-Effect Distillation. Desalination 2015, 366, 32-46. [CrossRef]

49. Andrés-Mañas, J.A.; Roca, L.; Ruiz-Aguirre, A.; Acién, F.G.; Gil, J.D.; Zaragoza, G. Application of solar energy to seawater desalination in a pilot system based on vacuum multi-effect membrane distillation. Appl. Energy 2020, 258, 114068. [CrossRef]

50. Xue, Y.; Du, X.; Ge, Z.; Yang, L. Study on multi-effect distillation of seawater with low-grade heat utilization of thermal power generating unit. Appl. Therm. Eng. 2018, 141, 589-599. [CrossRef]

51. Liponi, A.; Wieland, C.; Baccioli, A. Multi-effect distillation plants for small-scale seawater desalination: Thermodynamic and economic improvement. Energy Convers. Manage. 2020, 205, 1-14. [CrossRef]

52. Alsehli, M.; Saleh, B.; Elfasakhany, A.; Aly, A.A.; Bassuoni, M.M. Experimental study of a novel solar multi-effect distillation unit using alternate storage tanks. J. Water Reuse Desalination 2020, 10, 120-132. [CrossRef]

53. Guo, P.; Li, T.; Li, P.; Zhai, Y.; Li, J. Study on a novel spray-evaporation multi-effect distillation desalination system. Desalination 2020, 473, 1-11. [CrossRef]

54. Guo, P.; Li, P.; Li, J. Assessment of Water Droplet Evaporation Path in a Full Separation MED Desalination System. Heat Trans. Therm. Eng. 2016, 8. [CrossRef]

55. Al-hotmani, O.M.A.; Al-Obaidi, M.A.; Filippini, G.; Manenti, F.; Patel, R.; Mujtaba, I.M. Optimisation of multi effect distillation based desalination system for minimum production cost for freshwater via repetitive simulation. Comput. Chem. Eng. 2020, 135, 1-9. [CrossRef]

56. Cuviella, C.; Colmenar, A.; Borge, D.; López, A. Heat recovery in sanitary-ware industry applied to water and energy saving by multi-effect distillation. J. Clean. Prod. 2019, 213, 1322-1336. [CrossRef]

57. Goodarzi, S.; Jahanshahi, J.E.; Rahnama, M.; Ahmadi, M. Techno-economic evaluation of a multi effect distillation system driven by low-temperature waste heat from exhaust flue gases. Desalination 2019, 460, 64-80. [CrossRef]

58. Khalilzadeh, S.; Hossein, N.A. Utilization of waste heat of a high-capacity wind turbine in multi effect distillation desalination: Energy, exergy and thermoeconomic analysis. Desalination 2018, 439, 119-137. [CrossRef]

59. Touati, K.; de la Calle, A.; Tadeo, F.; Roca, L.; Schiestel, T.; Alarcón, D.C. Energy recovery using salinity differences in a multi-effect distillation system. Desalination Water Treat. 2015, 55, 3048-3055. [CrossRef]

60. Chorak, A.; Palenzuela, P.; Alarcón, D.C.; Abdellah, A.B. Energetic evaluation of a double-effect LiBr-H2O absorption heat pump coupled to a multi-effect distillation plant at nominal and off-design conditions. Appl. Therm. Eng. 2018, 142, 543-554. [CrossRef]

61. Aroussy, Y.; Saifaoui, D.; Lilane, A.; Tarfaoui, M. Thermo-economic simulation and analysis of a solar thermal cycle combined with two desalination processes by multi-effect distillation (MED). Mater. Today Proc. 2020, 30, 1027-1032. [CrossRef]

62. Khorshidi, J.; Pour, N.S.; Zarei, T. Exergy Analysis and Optimization of Multi-effect Distillation with Thermal Vapor Compression System of Bandar Abbas Thermal Power Plant Using Genetic Algorithm. Iran. J. Sci. Technol. Trans. Mech. Eng. 2019, 43, 13-24. [CrossRef]

63. Abadi, S.M.A.N.R.; Kouhikamali, R. CFD-aided mathematical modeling of thermal vapor compressors in multiple effects distillation units. Appl. Math. Modell. 2016, 40, 6850-6868. [CrossRef]

64. Wang, C.; Wang, L.; Wang, X.; Zhao, H. Design and numerical investigation of an adaptive nozzle exit position ejector in multi-effect distillation desalination system. Energy 2017, 140, 673-681. [CrossRef]

65. Thu, K.; Kim, Y.D.; Amy, G.; Chun, W.G.; Ng, K.C. A hybrid multi-effect distillation and adsorption cycle. Appl. Energy 2013, 104, 810-821. [CrossRef]

66. Hu, J.; Xu, S.; Wu, X.; Wu, D.; Jin, D.; Wang, P.; Xu, L.; Leng, Q. Exergy analysis for the multi-effect distillation-Reverse electrodialysis heat engine. Desalination 2019, 467, 158-169. [CrossRef]

67. Bamufleh, H.; Abdelhady, F.; Baaqeel, H.M.; El-Halwagi, M.M. Optimization of multi-effect distillation with brine treatment via membrane distillation and process heat integration. Desalination 2017, 408, 110-118. [CrossRef]

68. Birney, C.I.; Jones, M.C.; Webber, M.E. A spatially resolved thermodynamic assessment of geothermal powered multi-effect brackish water distillation in Texas. Resources 2019, 8, 65. [CrossRef]

69. Mohammadi, K.; Saghafifar, M.; Ellingwood, K.; Powell, K. Hybrid concentrated solar power (CSP)-desalination systems: A review. Desalination 2019, 468, 114083. [CrossRef]

70. Hamed, O.A.; Kosaka, H.; Bamardouf, K.H.; Al-Shail, K.; Al-Ghamdi, A.S. Concentrating solar power for seawater thermal desalination. Desalination 2016, 396, 70-78. [CrossRef]

71. Saldivia, D.; Rosales, C.; Barraza, R.; Cornejo, L. Computational analysis for a multi-effect distillation (MED) plant driven by solar energy in Chile. Renew. Energy 2019, 132, 206-220. [CrossRef]

72. De la Calle, A.; Bonilla, J.; Roca, L.; Palenzuela, P. Dynamic modeling and simulation of a solar-assisted multi-effect distillation plant. Desalination 2015, 357, 65-76. [CrossRef]

73. De la Calle, A.; Bonilla, J.; Roca, L.; Palenzuela, P. Dynamic modeling and performance of the first cell of a multi-effect distillation plant. Appl. Therm. Eng. 2014, 70, 410-420. [CrossRef]

74. Leiva, R.; Escobar, R.; Cardemil, J.M.; Alarcón, D.C.; Uche, J.; Martínez, A. Exergy cost assessment of CSP driven multi-generation schemes: Integrating seawater desalination, refrigeration, and process heat plants. Energy Convers. Manag. 2019, 179, 249-269. [CrossRef] 
75. Elbar, A.R.A.; Hassan, H. Enhancement of hybrid solar desalination system composed of solar panel and solar still by using porous material and saline water preheating. Sol. Energy 2020, 204, 382-394. [CrossRef]

76. Chorak, A.; Palenzuela, P.; Alarcón, D.C.; Abdellah, A.B. Experimental characterization of a multi-effect distillation system coupled to a flat plate solar collector field: Empirical correlations. Appl. Therm. Eng. 2017, 120, 298-313. [CrossRef]

77. Frantz, C.; Seifert, B. Thermal Analysis of a Multi Effect Distillation Plant Powered by a Solar Tower Plant. Energy Procedia 2015, 69, 1928-1937. [CrossRef]

78. Askari, I.B.; Ameri, M. Techno economic feasibility analysis of Linear Fresnel solar field as thermal source of the MED/TVC desalination system. Desalination 2016, 394, 1-17. [CrossRef]

79. Alhaj, M.; Al-Ghamdi, S.G. Technical and environmental perspectives on solar-driven seawater desalination: A case study of multieffect distillation. In World Environmental and Water Resources Congress 2019: Groundwater, Sustainability, Hydro-Climate/Climate Change, and Environmental Engineering, Proceedings of the World Environmental and Water Resources Congress, Pittsburgh, PA, USA, 19-23 May 2019; American Society of Civil Engineers (ASCE): Reston, VA, USA, 2019. [CrossRef]

80. Alhaj, M.; Mabrouk, A.; Al-Ghamdi, S.G. Energy efficient multi-effect distillation powered by a solar linear Fresnel collector. Energy Convers. Manag. 2018, 171, 576-586. [CrossRef]

81. Palenzuela, P.; Zaragoza, G.; Alarcón, D.C. Characterisation of the coupling of multi-effect distillation plants toconcentrating solar power plants. Energy 2015, 82, 986-995. [CrossRef]

82. Ortega, B.; Palenzuela, P.; Alarcón, D.C.; García, L. Quasi-steady state simulations of thermal vapor compression multi-effect distillation plants coupled to parabolic trough solar thermal power plants. Desalination Water Treat. 2016, 57, 23085-23096. [CrossRef]

83. Sharan, P.; Neises, T.; McTigue, J.D.; Turchi, C. Cogeneration using multi-effect distillation and a solar-powered supercritical carbon dioxide Brayton cycle. Desalination 2019, 459, 20-33. [CrossRef]

84. Sharan, P.; Neises, T.; Turchi, C. Optimal feed flow sequence for multi-effect distillation system integrated with supercritical carbon dioxide Brayton cycle for seawater desalination. J. Clean. Prod. 2018, 196, 889-901. [CrossRef]

85. Palenzuela, P.; Miralles, S.; Cabrera, A.; Cornejo, L. Techno-economic assessment of a multi-effect distillation plant installed for the production of irrigation water in Arica (Chile). Sci. Total Environ. 2018, 643, 423-434. [CrossRef]

86. Tarpani, R.R.Z.; Miralles, S.; Gallego, A.; Cabrera, A.; Cornejo, L. Environmental assessment of sustainable energy options for multi-effect distillation of brackish water in isolated communities. J. Clean. Prod. 2019, 213, 1371-1379. [CrossRef]

87. Hamed, O.A. Thermal Desalination: Performance and Challenges. In Corrosion and Fouling Control in Desalination Industry; Saji, V.S., Meroufel, A.A., Sorour, A.A., Eds.; Springer Nature: Cham, Switzerland, 2020; ISBN 978-3-030-34283-8.

88. Pandey, P.; Prakash, O.; Kumar, A. Desalination and Solar Still: Boon to Earth. In Solar Desalination Technology. Green Energy and Technology; Kumar, A., Prakash, O., Eds.; Springer: Singapore, 2019; ISBN 978-981-13-6886-8.

89. Sommariva, C.; Syambabu, V.S.N. Increase in water production in UAE. Desalination 2001, 138, 173-179. [CrossRef]

90. Sharon, H.; Reddy, K.S. A review of solar energy driven desalination technologies. Renew. Sustain. Energy Rev. 2015, 41, 1080-1118. [CrossRef]

91. Mezher, T.; Fath, H.; Abbas, Z.; Khaled, A. Techno-economic assessment and environmental impacts of desalination technologies. Desalination 2011, 266, 263-273. [CrossRef]

92. Ullah, I.; Rasul, M.G. Recent developments in solar thermal desalination technologies: A review. Energies 2019, 12, 119. [CrossRef]

93. Toth, A.J. Modelling and optimisation of multi-stage flash distillation and reverse osmosis for desalination of saline process wastewater sources. Membranes 2020, 10, 265. [CrossRef] [PubMed]

94. Moharram, N.A.; Bayoumi, S.; Hanafy, A.A.; El-Maghlany, W.M. Hybrid desalination and power generation plant utilizing multi-stage flash and reverse osmosis driven by parabolic trough collectors. Case Stud. Therm. Eng. 2021, 23, 1-13. [CrossRef]

95. Marcovecchio, M.G.; Mussati, S.F.; Aguirre, P.A.; Scenna, N.J. Optimization of hybrid desalination processes including multi stage flash and reverse osmosis systems. Desalination 2005, 182, 111-122. [CrossRef]

96. Sanaye, S.; Asgari, S. Four E analysis and multi-objective optimization of combined cycle power plants integrated with Multi-stage Flash (MSF) desalination unit. Desalination 2013, 320, 105-117. [CrossRef]

97. Manesh, M.H.K.; Kabiri, S.; Yazdi, M.; Petrakopoulou, F. Exergoeconomic modeling and evaluation of a combined-cycle plant with MSF and MED desalination. J. Water Reuse Desalination 2020, 10, 158-172. [CrossRef]

98. Deymi, M.; Ebrahimi, A.; Valipour, S. Energy and exergy analyses of using natural gas compressor station waste heat for cogeneration power and fresh water. Int. J. Exergy 2019, 30, 139-156. [CrossRef]

99. Snoussi, A.; Chekir, N.; Ben Brahim, A. Entropy generation in multi-stage flash desalination plants. Int. J. Energy Environ. Eng. 2020, 11, 327-339. [CrossRef]

100. Hamed, O.A. Fuel utilization of steam power cycles integrated with multi-stage flash (MSF) desalination plants. Desalin Water Treat. 2019, 140, 7-13. [CrossRef]

101. Ezzeghni, U.A.; Abduljawad, M. Exergy Analysis of a Brine Mixing Once-Through MSF-BM Distillation Plant. AIJR Proc. 2018, 4, 687-696. [CrossRef]

102. Khoshrou, I.; Jafari Nasr, M.R.; Bakhtari, K. New opportunities in mass and energy consumption of the Multi-Stage Flash Distillation type of brackish water desalination process. Sol. Energy 2017, 153, 115-125. [CrossRef]

103. El-Ghonemy, A.M.K. Performance test of a sea water multi-stage flash distillation plant: Case study. AEJ 2018, 57, 2401-2413. [CrossRef] 
104. Lappalainen, J.; Korvola, T.; Alopaeus, V. Modelling and dynamic simulation of a large MSF plant using local phase equilibrium and simultaneous mass, momentum, and energy solver. Comput. Chem. Eng. 2017, 97, 242-258. [CrossRef]

105. Gao, H.; Jiang, A.; Huang, Q.; Xia, Y.; Gao, F.; Wang, J. Mode-based analysis and optimal operation of MSF desalination system. Processes 2020, 8, 794. [CrossRef]

106. Khoshrou, I.; Jafari Nasr, M.R.; Bakhtari, K. Exergy analysis of the optimized MSFD type of brackish water desalination process. Iran. J. Chem. Chem. Eng. 2017, 36, 191-208.

107. Darawsheh, I.; Islam, M.D.; Banat, F. Experimental characterization of a solar powered MSF desalination process performance. Therm. Sci. Eng. Prog. 2019, 10, 154-162. [CrossRef]

108. Lv, H.; Wang, Y.; Wu, L.; Hu, Y. Numerical simulation and optimization of the flash chamber for multi-stage flash seawater desalination. Desalination 2019, 465, 69-78. [CrossRef]

109. Kalendar, A.; Karar, S.; Kalendar, A. Improved desalinated water throughput using enhanced tubes in multi-stage flash desalination systems. JP J. Heat Mass Transf. 2019, 16, 207-220. [CrossRef]

110. Okazaki, T.; Kawara, Z.; Yokomine, T.; Kunugi, T. Enhancement of MSF using microbubbles. Int. J. Chem. React. Eng. 2015, 13, 469-475. [CrossRef]

111. Hassanean, M.; Nafey, A.; El-Maghraby, R.; Ayyad, F. Simulation of Multi-Stage Flash with Brine Circulating Desalination Plant. JPME 2019, 21, 34-42. [CrossRef]

112. Roy, Y.; Thiel, G.P.; Antar, M.A.; Lienhard, J.H. The effect of increased top brine temperature on the performance and design of OT-MSF using a case study. Desalination 2017, 412, 32-38. [CrossRef]

113. Bandi, C.S.; Uppaluri, R.; Kumar, A. Global optimization of MSF seawater desalination processes. Desalination 2016, 394, 30-43. [CrossRef]

114. Ali, M.B.; Kairouani, L. Multi-objective optimization of operating parameters of a MSF-BR desalination plant using solver optimization tool of Matlab software. Desalination 2016, 381, 71-83. [CrossRef]

115. Tenno, R.; Nguyen, P. Multistage Flash Evaporator Control in PDE Representation. IFAC Pap. Line 2016, 49, 70-75. [CrossRef]

116. Al-Hamahmy, M.; Fath, H.E.S.; Khanafer, K. Techno-economical simulation and study of a novel MSF desalination process. Desalination 2016, 386, 1-12. [CrossRef]

117. Wuryanti, S. Design of MSF type brine circulation system for steam power plant. J. Phys. Conf. Ser. 2020, 1450, 012049. [CrossRef]

118. Harandi, H.B.; Rahnama, M.; Jahanshahi, E.; Asadi, A. Performance optimization of a multi stage flash desalination unit with thermal vapor compression using genetic algorithm. Appl. Therm. Eng. 2017, 123, 1106-1119. [CrossRef]

119. Qi, C.H.; Lv, H.Q.; Feng, H.J.; Lv, Q.C. Seven-effect $2 \times 4500 \mathrm{~m}^{3} / \mathrm{d}$ low temperature multi-effect desalination plant. Part II: A comparative analysis. Desalin. Water Treat. 2017, 87, 14-26. [CrossRef]

120. Thabit, M.S.; Hawari, A.H.; Ammar, M.H.; Zaidi, S.; Zaragoza, G.; Altaee, A. Evaluation of forward osmosis as a pretreatment process for multi stage flash seawater desalination. Desalination 2019, 461, 22-29. [CrossRef]

121. Darwish, M.; Hassan, A.; Mabrouk, A.N.; Abdulrahim, H.; Sharif, A. Viability of integrating forward osmosis (FO) as pretreatment for existing MSF desalting unit. Desalin. Water Treat. 2016, 57, 14336-14346. [CrossRef]

122. Demir, M.E.; Dincer, I. Development and analysis of a new integrated solar energy system with thermal storage for fresh water and power production. Int. J. Energy Res. 2017, 42, 2864-2874. [CrossRef]

123. Azhar, M.S.; Rizvi, G.; Dincer, I. Integration of renewable energy based multigeneration system with desalination. Desalination 2017, 404, 72-78. [CrossRef]

124. Al-Othman, A.; Tawalbeh, M.; El Haj Assad, M.; Alkayyali, T.; Eisa, A. Novel multi-stage flash (MSF) desalination plant driven by parabolic trough collectors and a solar pond: A simulation study in UAE. Desalination 2018, 443, 237-244. [CrossRef]

125. Luqman, M.; Ghiat, I.; Maroof, M.; Lahlou, F.Z.; Bicer, Y.; Al-Ansari, T. Application of the concept of a renewable energy based-polygeneration system for sustainable thermal desalination process-A thermodynamics' perspective. Int. J. Energy Res. 2020, 10, 1-19. [CrossRef]

126. Alsehli, M.; Choi, J.K.; Aljuhan, M. A novel design for a solar powered multistage flash desalination. Sol. Energy 2017, 153, 348-359. [CrossRef]

127. Tiwari, G.N.; Sahota, L. Advanced Solar-Distillation Systems: Basic Principles, Thermal Modeling, and Its Application, 1st ed.; Springer: Singapore, 2017; ISBN 978-981-10-4671-1.

128. Zheng, H. Solar Energy Desalination Technology, 1st ed.; Elsevier Inc.: New York, NY, USA, 2016; Chapter 7; pp. 537-622, ISBN 978-0-12-805411-6.

129. Panagopoulos, A. Techno-economic evaluation of a solar multi-effect distillation/thermal vapor compression hybrid system for brine treatment and salt recovery. Chem. Eng. Process. 2020, 152, 1-9. [CrossRef]

130. Sharaf, M.A.; Nafey, A.S.; García-Rodríguez, L. Thermo-economic analysis of solar thermal power cycles assisted MED-VC (multi effect distillation-vapor compression) desalination processes. Energy 2011, 36, 2753-2764. [CrossRef]

131. Srithar, K.; Rajaseenivasan, T.; Arulmani, M.; Gnanavel, R.; Vivar, M.; Fuentes, M. Energy recovery from a vapour compression refrigeration system using humidification dehumidification desalination. Desalination 2018, 439, 155-161. [CrossRef]

132. Randon, A.; Rech, S.; Lazzaretto, A. Brine management: Techno-economic analysis of a mechanical vapor compression energy system for a near-zero liquid discharge application. Int. J. Thermodyn. 2020, 23, 128-137. [CrossRef]

133. Jamil, M.A.; Zubair, S.M. On thermoeconomic analysis of a single-effect mechanical vapor compression desalination system. Desalination 2017, 420, 292-307. [CrossRef] 
134. He, W.F.; Zhu, W.P.; Xia, J.R.; Han, D. A mechanical vapor compression desalination system coupled with a transcritical carbon dioxide Rankine cycle. Desalination 2018, 425, 1-11. [CrossRef]

135. Han, D.; He, W.F.; Yue, C.; Pu, W.H. Study on desalination of zero-emission system based on mechanical vapor compression. Appl. Energy 2017, 185, 1490-1496. [CrossRef]

136. Chen, Q.; Ja, M.K.; Li, Y.; Chua, K.J. Energy, exergy and economic analysis of a hybrid spray-assisted low-temperature desalination/thermal vapor compression system. Energy 2019, 166, 871-885. [CrossRef]

137. Dong, Z.; Liu, M.; Huang, X.; Zhang, Y.; Zhang, Z.; Dong, Y. Dynamical modeling and simulation analysis of a nuclear desalination plant based on the MED-TVC process. Desalination 2019, 456, 121-135. [CrossRef]

138. Panagopoulos, A. Process simulation and techno-economic assessment of a zero liquid discharge/multi-effect desalination/thermal vapor compression (ZLD/MED/TVC) system. Int. J. Energy Res. 2020, 44, 473-495. [CrossRef]

139. Dong, J.; Wang, W.; Han, Z.; Ma, H.; Deng, Y.; Su, F.; Pan, X. Experimental investigation of the steam ejector in a single-effect thermal vapor compression desalination system driven by a low-temperature heat source. Energies 2018, 11, 2282. [CrossRef]

140. Elsayed, M.L.; Mesalhy, O.; Mohammed, R.H.; Chow, L.C. Effect of input parameters intensity and duration on dynamic performance of MED-TVC plant. Appl. Therm. Eng. 2018, 137, 475-486. [CrossRef]

141. Wen, C.; Ding, H.; Yang, Y. Performance of steam ejector with nonequilibrium condensation for multi-effect distillation with thermal vapour compression (MED-TVC) seawater desalination system. Desalination 2020, 489, 114531. [CrossRef]

142. Khalid, K.A.; Antar, M.A.; Khalifa, A.; Hamed, O.A. Allocation of thermal vapor compressor in multi effect desalination systems with different feed configurations. Desalination 2018, 426, 164-173. [CrossRef]

143. Wang, K.; Wang, L.; Jia, L.; Cai, W.; Gao, R. Optimization design of steam ejector primary nozzle for MED-TVC desalination system. Desalination 2019, 471, 114070. [CrossRef]

144. Gu, W.; Wang, X.; Wang, L.; Yin, X.; Liu, H. Performance investigation of an auto-tuning area ratio ejector for MED-TVC desalination system. Appl. Therm. Eng. 2019, 155, 470-479. [CrossRef]

145. Xue, H.; Wang, L.; Jia, L.; Xie, C.; Lv, Q. Design and investigation of a two-stage vacuum ejector for MED-TVC system. Appl. Therm. Eng. 2020, 167, 114713. [CrossRef]

146. Zhou, S.; Gong, L.; Liu, X.; Shen, S. Mathematical modeling and performance analysis for multi-effect evaporation/multi-effect evaporation with thermal vapor compression desalination system. Appl. Therm. Eng. 2019, 159, 113759. [CrossRef]

147. Onishi, V.C.; Carrero, A.; Reyes, J.A.; Ruiz, R.; Salcedo, R.; Fraga, E.S.; Caballero, J.A. Shale gas flowback water desalination: Single vs multiple-effect evaporation with vapor recompression cycle and thermal integration. Desalination 2017, 404, 230-248. [CrossRef]

148. Elsayed, M.L.; Mesalhy, O.; Mohammed, R.H.; Chow, L.C. Performance modeling of MED-MVC systems: Exergy-economic analysis. Energy 2019, 166, 552-568. [CrossRef]

149. Cao, Z.; Deng, J.; Ye, F.; Garris, C.A. Analysis of a hybrid Thermal Vapor Compression and Reverse Osmosis desalination system at variable design conditions. Desalination 2018, 438, 54-62. [CrossRef]

150. Sadri, S.; Ameri, M.; Haghighi, R. Multi-objective optimization of MED-TVC-RO hybrid desalination system based on the irreversibility concept. Desalination 2017, 402, 97-108. [CrossRef]

151. Swaminathan, J.; Nayar, K.G.; Lienhard, J.H. Mechanical vapor compression-Membrane distillation hybrids for reduced specific energy consumption. Desalin Water Treat. 2016, 57, 26507-26517. [CrossRef]

152. Askalany, A.A. Innovative mechanical vapor compression adsorption desalination (MVC-AD) system. Appl. Therm. Eng. 2016, 106, 286-292. [CrossRef]

153. Elsayed, M.L.; Mesalhy, O.; Mohammed, R.H.; Chow, L.C. Exergy and thermo-economic analysis for MED-TVC desalination systems. Desalination 2018, 447, 29-42. [CrossRef]

154. Ghaebi, H.; Abbaspour, G. Performance analysis and thermodynamic modeling of a poly generation system by integrating a multi-effect-desalination thermo-vapor compression (MED-TVC) system with a combined cooling, heating and power (CCHP) system. J. Therm. Eng. 2018, 4, 1963-1983. [CrossRef]

155. Ghaebi, H.; Abbaspour, G. Thermoeconomic analysis of an integrated multi-effect desalination thermal vapor compression (MED-TVC) system with a trigeneration system using triple-pressure HRSG. Heat Mass Transf. 2018, 54, 1337-1357. [CrossRef]

156. Ghazi, M.; Essadiqi, E.; Faqir, M.; Mada, M.; Abdellah, A.B. Study and Design of Hybrid Wind-Photovoltaic System for Medium Scale Mechanical Vapor Compression Desalination Unit for Two Different Sites in Morocco. In Proceedings of the 2017 International Renewable and Sustainable Energy Conference (IRSEC), Tangier, Morocco, 4-7 December 2017; pp. 1-6. [CrossRef]

157. Omar, A.; Nashed, A.; Li, Q.; Leslie, G.; Taylor, R.A. Pathways for integrated concentrated solar power-Desalination: A critical review. Renew. Sustain. Energy Rev. 2020, 119, 1-17. [CrossRef]

158. Al-Sahali, M.; Ettouney, H. Developments in thermal desalination processes: Design, energy, and costing aspects. Desalination 2007, 214, 227-240. [CrossRef]

159. Ali, A.; Tufa, R.A.; Macedonio, F.; Curcio, E.; Drioli, E. Membrane technology in renewable-energy-driven desalination. Renew. Sustain. Energy Rev. 2018, 81, 1-21. [CrossRef]

160. Alsarayreh, A.A.; Al-Obaidi, M.A.; Al-Hroub, A.M.; Patel, R.; Mujtaba, I.M. Evaluation and minimisation of energy consumption in a medium-scale reverse osmosis brackish water desalination plant. J. Clean. Prod. 2020, 248, 1-16. [CrossRef]

161. Mehmood, A.A.; Waqas, A.; Said, Z.; Rahman, S.M.A.; Akram, M. Performance evaluation of solar water heating system with heat pipe evacuated tubes provided with natural gas backup. Energy Rep. 2019, 5, 1432-1444. [CrossRef] 
162. Mehmood, A.A.; Ren, J. Renewable energy-driven desalination for more water and less carbon. In Renewable-Energy-Driven Future; Ren, J., Ed.; Academic Press: London, UK, 2021; pp. 333-372, ISBN 978-0-12-8205396.

163. Abutayeh, M.; Li, C.; Goswami, D.Y.; Stefanakos, E.K. Solar Desalination. In Desalination: Water from Water, 2nd ed.; Kucera, J., Ed.; Wiley-Scrivener: Beverly, MA, USA, 2019; pp. 551-582, ISBN 978-1-119-40789-8.

164. Mehrjerdi, H. Modeling and optimization of an island water-energy nexus powered by a hybrid solar-wind renewable system. Energy 2020, 197, 1-11. [CrossRef]

165. Padrón, I.; Avila, D.; Marichal, G.N.; Rodríguez, J.A. Assessment of Hybrid Renewable Energy Systems to supplied energy to Autonomous Desalination Systems in two islands of the Canary Archipelago. Renew. Sustain. Energy Rev. 2019, 101, 221-230. [CrossRef]

166. Alhaj, M.; Al-Ghamdi, S.G. Why is powering thermal desalination with concentrated solar power expensive? Assessing economic feasibility and market commercialization barriers. Sol. Energy 2019, 189, 480-490. [CrossRef]

167. Anis, S.F.; Hashaikeh, R.; Hilal, N. Reverse osmosis pretreatment technologies and future trends: A comprehensive review. Desalination 2019, 452, 159-195. [CrossRef]

168. Brendel, L.P.M.; Shah, V.M.; Groll, E.A.; Braun, J.E. A methodology for analyzing renewable energy opportunities for desalination and its application to Aruba. Desalination 2020, 493, 1-11. [CrossRef]

169. Pouyfaucon, A.B.; García-Rodríguez, L. Solar thermal-powered desalination: A viable solution for a potential market. Desalination 2018, 435, 60-69. [CrossRef]

170. Al-Hrari, M.; Ceylan, İ.; Nakoa, K.; Ergün, A. Concentrated photovoltaic and thermal system application for fresh water production. Appl. Therm. Eng. 2020, 171, 1-13. [CrossRef]

171. Baaqeel, H.; Abdelhady, F.; Alghamdi, A.S.; El-Halwagi, M.M. Optimal design and scheduling of a solar-assisted domestic desalination systems. Comput. Chem. Eng. 2020, 132, 1-9. [CrossRef]

172. Faegh, M.; Behnam, P.; Shafii, M.B. A review on recent advances in humidification-dehumidification (HDH) desalination systems integrated with refrigeration, power and desalination technologies. Energy Convers. Manag. 2019, 196, 1002-1036. [CrossRef]

173. Lawal, D.U.; Qasem, N.A.A. Humidification-dehumidification desalination systems driven by thermal-based renewable and low-grade energy sources: A critical review. Renew. Sustain. Energy Rev. 2020, 125, 1-51. [CrossRef]

174. Kasaeian, A.; Babaei, S.; Jahanpanah, M.; Sarrafha, H.; Sulaiman Alsagri, A.; Ghaffarian, S.; Yan, W.M. Solar humidificationdehumidification desalination systems: A critical review. Energy Convers. Manag. 2019, 201, 1-26. [CrossRef]

175. Al-Otoom, A.; Al-Khalaileh, A.T. Water desalination using solar continuous humidification-dehumidification process using hygroscopic solutions and rotating belt. Sol. Energy 2020, 197, 38-49. [CrossRef]

176. Gabrielli, P.; Gazzani, M.; Novati, N.; Sutter, L.; Simonetti, R.; Molinaroli, L.; Manzolinic, G.; Mazzotti, M. Combined water desalination and electricity generation through a humidification-dehumidification process integrated with photovoltaic-thermal modules: Design, performance analysis and techno-economic assessment. Energy Convers. Manag. X 2019, 1, 1-18. [CrossRef]

177. Giwa, A.; Yusuf, A.; Dindi, A.; Balogun, H.A. Polygeneration in desalination by photovoltaic thermal systems: A comprehensive review. Renew. Sustain. Energy Rev. 2020, 130,1-19. [CrossRef]

178. Xu, H.; Ji, X.; Wang, L.; Huang, J.; Han, J.; Wang, Y. Performance study on a small-scale photovoltaic electrodialysis system for desalination. Renew. Energy 2020, 154, 1008-1013. [CrossRef]

179. Campione, A.; Cipollina, A.; Calise, F.; Tamburini, A.; Galluzzo, M.; Micale, G. Coupling electrodialysis desalination with photovoltaic and wind energy systems for energy storage: Dynamic simulations and control strategy. Energy Convers. Manag. 2020, 216, 1-15. [CrossRef]

180. Zhang, Y.; Sivakumar, M.; Yang, S.; Enever, K.; Ramezanianpour, M. Application of solar energy in water treatment processes: A review. Desalination 2018, 428, 116-145. [CrossRef]

181. Li, C.; Goswami, Y.; Stefanakos, E. Solar assisted sea water desalination: A review. Renew. Sustain. Energy Rev. 2013, 19, 136-163. [CrossRef]

182. Piacentino, A. Application of advanced thermodynamics, thermoeconomics and exergy costing to a Multiple Effect Distillation plant: In-depth analysis of cost formation process. Desalination 2015, 371, 88-103. [CrossRef]

183. Kouhikamali, R. Thermodynamic analysis of feed water pre-heaters in multiple effect distillation systems. Appl. Therm. Eng. 2013, 50, 1157-1163. [CrossRef]

184. Elsaid, K.; Taha Sayed, E.; Yousef, B.A.A.; Hussien Rabaia, M.K.; Ali Abdelkareem, M.; Olabi, A.G. Recent progress on the utilization of waste heat for desalination: A review. Energy Convers. Manag. 2020, 221, 1-18. [CrossRef]

185. Olabi, A.G.; Elsaid, K.; Rabaia, M.K.H.; Askalany, A.A.; Abdelkareem, M.A. Waste heat-driven desalination systems: Perspective. Energy 2020, 209, 1-7. [CrossRef]

186. Ahmadi, A.; Ehyaei, M.A.; Doustgani, A.; El Haj Assad, M.; Hmida, A.; Jamali, D.H.; Kumar, R.; Li, Z.X.; Razmjoo, A. Recent residential applications of low-temperature solar collector. J. Clean. Prod. 2021, 279, 1-32. [CrossRef]

187. Chandrashekara, M.; Yadav, A. Water desalination system using solar heat: A review. Renew. Sustain. Energy Rev. 2017, 67, 1308-1330. [CrossRef] 